\title{
Breeding success of Cacicus haemorrhous (Linnaeus) (Aves: Icteridae) in different environments in an Atlantic Forest reserve in Southeast Brazil
}

\author{
Charles Duca ${ }^{1} \&$ Miguel Ângelo Marini ${ }^{2}$ \\ 1 Programa de Pós-Graduação em Ecologia, Conservação e Manejo da Vida Silvestre, Universidade Federal de Minas Gerais. \\ Caixa Postal 486, 30161-970 Belo Horizonte, Minas Gerais, Brasil. E-mail: chduca@ig.com.br \\ ${ }^{2}$ Corresponding author. Departamento de Zoologia, Instituto de Biologia, Universidade de Brasília. $70910-900$ Brasília, \\ Distrito Federal, Brasil.
}

\begin{abstract}
Several factors, including the site where the colony was established and number of active nests can influence directly or indirectly the breeding success of colonial birds. The red-rumped cacique, Cacicus haemorrhous (Linnaeus, 1766), is a passerine (Icteridae) that breeds in colonies in different environments. The objective of this study was to evaluate the breeding success of red-rumped cacique in relation to three environments (lake edge, forest and swamp) in which colonies were established in an Atlantic Forest reserve in southeast Brazil. Seven colonies from the three environments were monitored during the breeding season of 2001. Overall probability of nest survival was $\mathbf{4 0 . 5 \%}$. We found that colonies established in the swamp presented higher nest survival than the others and the ones in the lake edge had lower survival. Nest predation was the most important cause of nest failure, representing $46.5 \%$ of all nest losses. Other failure causes were abandonment and fall of nests, representing $6.6 \%$ and $6.1 \%$ of the losses, respectively. Red-rumped cacique had higher success breeding in colonies located in the swamp.

KEY WORDS. Nest predation; red-rumped cacique; reproduction.
\end{abstract}

\begin{abstract}
RESUMO. Sucesso reprodutivo de Cacicus haemorrhous (Linnaeus) (Aves: Icteridae) em diferentes ambientes de uma reserva de Mata Atlântica no sudeste do Brasil. Diversos fatores, incluindo os locais onde as colônias são estabelecidas e o número de ninhos ativos, podem exercer uma influência direta ou indireta no sucesso reprodutivo de aves que reproduzem em colônias. O Guaxe é uma espécie de Passeriformes (Icteridae) que se reproduz em colônias situadas em diferentes ambientes. O objetivo deste estudo foi avaliar o sucesso reprodutivo de Cacicus haemorrhous (Linnaeus, 1766) em relação a três ambientes (margem de lago, floresta e brejo) onde são estabelecidas colônias em uma reserva de Mata Atlântica no sudeste do Brasil. Sete colônias foram monitoradas durante a estação reprodutiva de 2001 apresentando uma probabilidade de sobrevivência dos ninhos de 40,5\%. As colônias estabelecidas em brejos apresentaram sucesso reprodutivo significativamente maior do que colônias estabelecidas nos outros ambientes (margem de lago e floresta). A predação foi o fator mais importante de perdas de ninhadas, com $46,5 \%$ dos ninhos predados. Outras causas de perdas de ninhadas foram o abandono e a queda de ninhos, representando 6,6\% e 6,1\% das perdas, respectivamente. Cacicus haemorrhous obtém maior sucesso reprodutivo em colônias localizadas em área de brejo.

PALAVRAS CHAVE. Guaxe; predação de ninhos; reprodução.
\end{abstract}

Most studies about avian breeding success shows that predation is the main factor of brood loss (Martin 1993, AgulLaR et al. 2000, Picman et al. 2002). The quality of the breeding habitat has been considered as another important factor in breeding success. Some breeding habitats provide better food resources (WITTENBERGER 1980), while others are safer against predators (LENINGTON 1980) or better protected against variations from climatic extremes (PleszcZynsKa 1978).

For several species of colonial birds, variables such as sites of colony establishment, number of active nests, and degree of nest grouping have been considered factors that influence di- rectly or indirectly the breeding success (TENAzA 1971, Robinson 1985, Massoni \& Reboreda 2001). These factors influence in predator vulnerability and are related to the probability of nest desertion (MASSONI \& ReBoreda 2001). According to Horn (1968), while one strategy can be efficient for some predators, this strategy can result in a greater vulnerability to other types of predators. Therefore, colonial species that are attacked by several kinds of predators have to deal with a variety of selective pressures that favors different sites of colonies establishment and different spatial distributions of nests within colonies (RobINson 1985).

Revista Brasileira de Zoologia 25 (2): 165-171, June, 2008 
The red-rumped cacique, Cacicus haemorrhous (Linnaeus, 1766), is an exclusively Neotropical Icteridae that occurs throughout the Amazon region; southeast and central-west of Brazil; east of Andes; Colombia; Paraguay and northeast of Argentina (PARKes 1970, Sick 1997). It inhabits humid tropical forests, including gallery forests. It is common in canopies and forest edges, river banks and clearing (FEEKES 1981, RIDGELY \& TUdOR 1989). It is a species that breeds in colonies, weaving nests in a bag form, suspended from the extremity of branches from tall and smooth trunk trees in the middle of the forest and forest edges or on branches over water (FEEKES 1981, SICK 1997). It can occur in mixed colonies, associated with Crested oropendola (Psarocolius decumanus, Pallas 1769) (Icteridae) or yellow-rumped cacique (Cacicus cela, Linnaeus 1758) (Icteridae) (SICK 1997). In the study area, red-rumped cacique breeding sites can be separated in at least three environmental types, with variable vulnerability to nest predators. The three environments considered in this study were lake edge, forest clearing and swamp.

Thus, breeding aspects were studied in order to evaluate the role of colony sites and predation in the breeding success of red-rumped cacique in the study area. Our specific objective was to evaluate difference in the breeding success related to three environments (lake edge, forest clearing and swamp) in the study area.

\section{MATERIAL AND METHODS}

\section{Study area}

The study was conducted in Parque Estadual do Rio Doce (PERD), located between $19^{\circ} 48^{\prime}-19^{\circ} 29^{\prime} \mathrm{S}$ and $42^{\circ} 38^{\prime}-48^{\circ} 28^{\prime} \mathrm{W}$, in the Rio Doce Valley, southeast Brazil. The park has 35,974 ha, with altitudes varying from 230 to $515 \mathrm{~m}$ above the sea level (Cetec 1981 apud Tundisi \& SAIJo 1997). The natural limits of the park are the Doce River to the east and Piracicaba River to the north. The presence of 38 lakes occupying $6 \%$ of the park's total area characterizes the landscape. The climemate is humid tropical, with rainy season from October to March and dry season from April to September.

The PERD is covered by vegetation that receives several denominations in the literature. According to Veloso et al. (1991), the park vegetation is named "Sub-mountainous Semideciduous Forest". Outside the park's limits, there is a predominance of Eucalyptus spp., pasture lands, agriculture and forest fragments (SIF 1990).

\section{Nest colony classification}

It was considered as a colony a group of two or more nests established in bushes or trees, and simultaneously active during the breeding period, with movement of the individuals between nests or nest cluster. Groups of two or more active nests built on branches pending over water and the tree trunk in dry soil (without mud or water) were considered as lake edge colonies. Nests established on a tree in forest clearings or near human buildings and not associated to aquatic environments were considered as forest colonies. Nests established on trees or shrubs existent in flooded and muddy sites were considered as swamp colonies.

\section{Data collection}

Seven colonies were monitored at three-day intervals during the breeding season of 2001. A map of the colonies was elaborated and each nest was plotted and received an identification number. During visits, nests' contents were inspected. Most nests were located on a position in the colony tree where we were able to access them and see their contents directly. To inspect the nests located in a difficult location to be accessed by the observers, we used two strategies: 1 ) we used a stick with a small mirror fixed at the end and looked at the contents reflected in the mirror with aid of binoculars or; 2) we observed the nests with binoculars and assumed their contents based on the behavior of their owners. During nest observations, when the female stayed inside the nest for a long time (at least $20 \mathrm{~min}$.) and when it was not carrying food items during the observation, we assumed that the contents of the nest were eggs. When we observed the female bringing food items and feeding the nestlings, we assumed that the contents of the nest were nestlings. To avoid disturbances in the colony, many times we used the second strategy even to re-inspect accessible nests that had their contents observed directly during the previous inspection. For each nest, the following data was recorded: initial and final nest building dates, laying and hatching dates, and dates when the nestlings left the nest, or when the nest was either abandoned or predated. This monitoring had the objective to evaluate breeding success and also to know in which nest phase nest loss was highest. Seven colonies were monitored, two of lake edge, two of forest, and three of swamps. Colonies were considered active from the date that the first female laid eggs to the date that the last nest in the colony became inactive.

Nests were considered successful when at least one nestling left the nest. Nests that were found empty, without any sign of damage in their structure caused by predation and those with nestling aged over 21 days, were considered successful. When found empty before the nestling's age of 21 days, usually presenting traces of predatory actions, such as damage to its structure, blood traces and/or feathers, the nest was considered predated. Nest containing dead nestling with signs of aggression, such as injuries and beak marks, were also considered predated. Nests were considered abandoned when eggs remained (intact) in the nest for more than 25 days. Nest found with dead nestling without any signs of aggression were considered abandoned. Other causes of nests losses were nest falling to the ground and destruction due to rainfall or other unknown factors. Nests abandoned before eggs were laid were not considered in the breeding success analysis.

\section{Data analyses}

For each colony, the percentage of successful nests was calculated, generating the percentage of successful nests for each environment (lake edge, forest and swamp). The nest sur- 
vival was also calculated according to Mayfield's protocol (MAYFIELd 1961, 1975). For each colony, the following was calculated: nest survival during incubation (\%NsI); nest survival during nestling period (\%NsN) and nest survival from start incubation to fledgling (\%Ns).

\section{Statistical analyses}

Kruskal-Wallis was applied to verify the difference in breeding success (\% of nest success) among the three environments. This test was also applied to assess if predation rate was different among the three environments (lake edge, forest and swamp). Qui-square Mantel-Haenszel test was applied to confirm the difference in breeding success among the three environments. To evaluate if nest survival probability (\%Ns) calculated by Mayfield's method and the nest success percentage (\% of nest success) supply the same information, a Wilcoxon test was applied. Non-parametric statistic was used due to the strong differences found within environments, especially between the two colonies of the lake edge (Tabs I and II). Linear regressions were used to evaluate the relationship between: a) number of nests and nest survival probability (\%Ns); b) number of nests with predation rate and; c) number of nests with overall nest failure. All tests were applied according to OTт (1988) and TRIOLA (1999) and conducted in a Statistica statistical package (STATSOFT 1995). In result, the standard error (SE) was used and a significance level of $5 \%$ was applied.

\section{RESULTS}

Considering all nests $(n=296)$, including the ones that were lost or abandoned before eggs were laid, the colonies varied from 9 to 85 nests, with mean of $42.3 \pm 30.7$ nests. In those colonies, the number of nests that had eggs varies from 7 to 74 nests, with mean of $32.6 \pm 24.6$ and a total of 228 nests (Tab. I). Thus, the analyses presented here refer to these 228 nests that had eggs during the study period.

\section{Nests predation}

Predation was the main factor of nest loss, with $46.5 \%$ of total losses caused by predator action. Lake edge colonies pre- sented higher predation rate, with $76.5 \%$ of their nests predated. The smallest predation rate was found in forest colonies, with $38.1 \%$ of their nests predated. The swamp colonies had $46.6 \%$ of their nests predated (Tab. I). However, the difference in predation rate among the three environments was not significant $(H=1,489$, d.f. $=2, p=0.475)$.

Overall predation rate during the incubation period was $21.9 \%$, with swamp colonies presenting the highest proportion $(25.7 \%)$ of the nests predated in this period. Predation during nestling period was $24.6 \%$, with lake edge colonies presenting the highest nestling predation rate (58.8\%) (Tab. I). We did not find difference in the nest predation rates between the incubation and nestling periods $(Z=1,577, p=0.115)$ when nest from all colonies were considered together.

\section{Nest abandonment and fall}

Nests were abandoned during several building phases. Out of 296 nests registered, 23\% were abandoned before eggs were laid. Some females practically finished nest building and later abandoned them without laying eggs. The smallest abandonment rate, before eggs were laid, occurred in swamp colonies (18.2\%), and the highest was in forest colonies (31\%). Lake edge colonies had $19 \%$ of their nests abandoned before eggs were laid.

Considering only nests that had eggs (228 nests), three (1.3\%) were abandoned during incubation and 12 (5.3\%) during the nestling period. Therefore, the abandonment of nests after eggs were laid represented $6.6 \%$ of brood losses in the study area (Tab. I). Other cause of brood loss was nest unfastening, causing its fall. The nest fall represented $6.1 \%$ of brood loss (Tab. I).

\section{Breeding success}

The breeding success of the red-rumped cacique in the study area calculated by the number of successful nests was $40.8 \%$ (Tab. I). Nest survival from start of incubation to fledgling (\%Ns) calculated through Mayfield's protocol presented similar result to the simple percentage (Tab. II).

There was no significant difference between nest survival probability (\%Ns) and the simple percentage of nest success (\% of nests that at least a nestling left the nest) $(Z=-0.676$,

Table I. Total number of nests, number of nests that have eggs and fate of red-rumped cacique in Parque Estadual do Rio Doce.

\begin{tabular}{lccccccccc}
\hline \multirow{2}{*}{ Environment Colony } & Total of & Nests with & \multicolumn{5}{c}{ Nests fate (\%) } \\
\cline { 5 - 9 } & & nests & eggs & Abandoned & Died nestling & Fallen nests & Predated eggs & Predated nestling & Nests successful \\
\hline Lake edge & 1 & 9 & 7 & $1(14.3)$ & $1(14.3)$ & 0 & $1(14.3)$ & $3(42.8)$ & $1(14.3)$ \\
& 2 & 12 & 10 & 0 & $1(10.0)$ & 0 & $2(20.0)$ & $7(70.0)$ & 0 \\
Forest & 3 & 46 & 31 & $2(6.4)$ & $3(9.7)$ & $5(16.1)$ & $3(9.7)$ & $6(19.3)$ & $12(38.7)$ \\
& 4 & 48 & 32 & 0 & $3(9.4)$ & $7(21.9)$ & $6(18.7)$ & $9(28.1)$ & $7(21.9)$ \\
Swamp & 5 & 19 & 18 & 0 & 0 & 0 & $2(11.1)$ & $2(11.1)$ & $14(77.8)$ \\
& 6 & 85 & 74 & 0 & $1(1.3)$ & 0 & $21(28.4)$ & $17(23.0)$ & $35(47.3)$ \\
& 7 & 77 & 56 & 0 & $3(5.3)$ & $2(3.6)$ & $15(26.8)$ & $12(21.4)$ & $24(42.8)$ \\
\hline Total & 296 & 228 & $3(1.3)$ & $12(5.3)$ & $14(6.1)$ & $50(21.9)$ & $56(24.6)$
\end{tabular}


$p=0.499)$. Since the two percentages denoted the same information, we considered as measure of breeding success the nest survival probabilities calculated through Mayfields' protocol.

Breeding success was significantly different among the three environments $\left(H=5.756\right.$, d.f. $=2, p=0.050$ and $\chi^{2}=18.958$, d.f. $=1, \mathrm{p}<0.001)$ (Tabs I and II). Lake edge colonies presented the smallest breeding success and swamp colonies presented the highest breeding success.

The number of nests in the colony was not significantly related to nest survival $(\% \mathrm{Ns})\left(\mathrm{r}^{2}=0.371\right.$, d.f. $\left.=6, \mathrm{p}=0.412\right)$, predation rate $\left(\mathrm{r}^{2}=0.038\right.$, d.f. $\left.=6, \mathrm{p}=0.676\right)$ and nest failure (all cause of nest loss combined) $\left(r^{2}=0.137\right.$, d.f. $\left.=6, p=0.414\right)$.

Lake edge colonies had mean activity duration (9.4 \pm 1.0 weeks) relatively smaller than forest $(13.0 \pm 1.8$ weeks $)$ and swamp (13.3 \pm 4.8 weeks) colonies, but this difference was not statistically significant $(\mathrm{H}=1.357$, d.f. $=2, \mathrm{p}=0.507)$. The analysis above was repeated considering only the time interval (9.4 weeks) in which colonies of the three environments were active. In this analysis it was observed a significant positive relationship between number of nests and nest survival (\%Ns) $\left(\mathrm{r}^{2}=0.824\right.$, d.f. $\left.=6, \mathrm{p}=0.023\right)$ (Fig. 1$)$ and a significant negative relationship between number of nests and nest failure (all causes of nest loss combined) $\left(r^{2}=0.609\right.$, d.f. $\left.=6, p=0.038\right)$. The relationship between number of nests and predation rate remained not significant $\left(\mathrm{r}^{2}=0.433\right.$, d.f. $\left.=6, \mathrm{p}=0.108\right)$.

Nest survival during incubation (\%NsI) was significantly higher than nest survival during nestling period (\%NsN) $(\mathrm{H}=$ 5.589 , d.f. $=1, \mathrm{p}=0.018$ ) (Tab. II).

Table II. Nest survival parameters of red-rumped cacique in three environments in Parque Estadual do Rio Doce. ${ }^{1}$ Nest survival during incubation; ${ }^{2}$ nest survival probability during nestling period; ${ }^{3}$ nest survival from start of incubation to fledgling.

\begin{tabular}{|c|c|c|c|c|}
\hline Environment & Colony & $\% \mathrm{Nsl}^{1}$ & $\% \mathrm{NsN}^{2}$ & $\% \mathrm{Ns}^{3}$ \\
\hline \multirow[t]{2}{*}{ Lake edge } & 1 & 72.0 & 26.3 & 19.0 \\
\hline & 2 & 79.1 & 3.3 & 2.6 \\
\hline \multirow[t]{2}{*}{ Forest } & 3 & 80.8 & 44.4 & 35.9 \\
\hline & 4 & 84.0 & 26.2 & 22.0 \\
\hline \multirow[t]{3}{*}{ Swamp } & 5 & 89.0 & 85.9 & 76.3 \\
\hline & 6 & 72.4 & 67.3 & 48.7 \\
\hline & 7 & 71.7 & 60.9 & 43.7 \\
\hline Total & & 76.3 & 53.1 & 40.5 \\
\hline
\end{tabular}

\section{DISCUSSION}

The number of red-rumped cacique nests varied considerably in colonies from each environment. The swamp was the environment where colonies presented the largest number of nests and also the highest breeding success. In the lake edge colonies it was observed the contrary, being also the environment with the highest predation rate in relation to the other two environments (forest and swamp). Sick (1997) stated that caciques

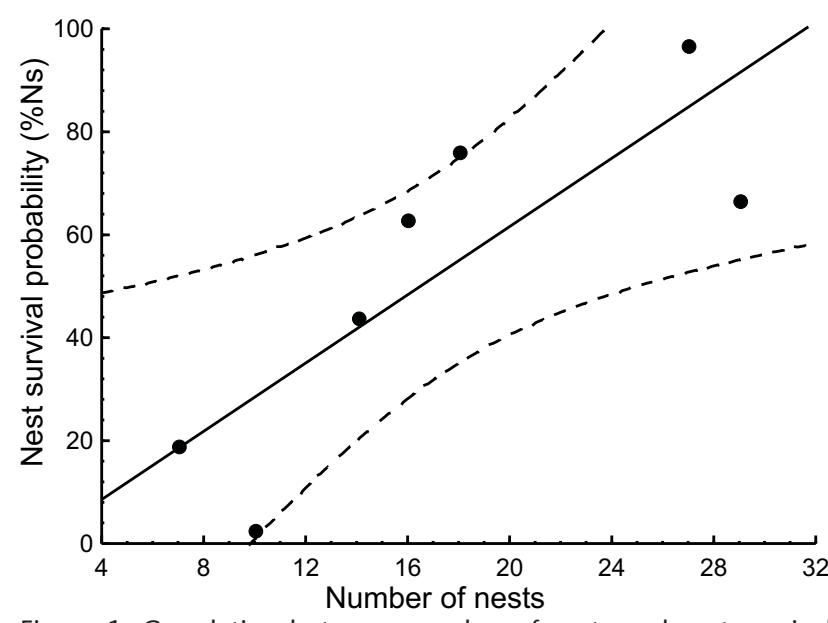

Figure 1. Correlation between number of nests and nest survival probability (\%Ns) of red-rumped cacique in Parque Estadual do Rio Doce. Dashed lines represent confident interval.

colonies sizes vary significantly and RoBinson (1985) has observed yellow-rumped cacique colonies varying from 2 to 250 nests, of which as many as 100 may be active at the same time.

\section{Nest predation}

Predation was the main factor of nests loss in the study area. Higher predation rate in colonies established in lakes and river edges was also observed for red-rumped cacique population in Suriname (FeEkes 1981) and yellow-rumped cacique population in Peru (RobINSON 1985), where the predation rate in this environment was $100 \%$ in five years of study. These authors attributed larger vulnerability in this environment to terrestrial and arboreal predators. It was observed that forest clearing and swamp sites were chosen by a larger number of females. Swamp colonies, which presented predation rates relatively smaller, had more than twice as many nests as lake edge colonies. Several studies have established an inverse relationship between colony size and nest predation rate (WESTNEAT 1992, Wiklund \& Andersson 1994, Picman et al. 2002). Therefore, the small number of nests in the lake edge colonies should be considered in the assessment of nests predation rate.

Several mechanisms can reduce predation in larger colonies. The frequency and efficiency of attack to predators can increase in larger colonies (Hoogland \& SHERMAN 1976, Robinson 1985), and predators can satiate themselves where preys are abundant and the probability of attack per nest is reduced (Foster \& Treherne 1981, Nisbet \& Welton 1984). However, many females breeding together can be harmful if predators are attracted to nest concentrations or by females movement, increasing the predation risk in very crowded areas. WEATHERHEAD \& ROBERTSON (1977) related that predation risk increase with female density in a red-winged blackbird (Agelaius phoeniceus, Linnaeus 1766) (Icteridae) population, but this relation was not observed in another population of the same species (CACCAMISE 1976). 
Nestling predation rate $(24.6 \%)$ was slightly larger than eggs predation rate $(21.9 \%)$, however this difference was not statistically significant. Aguilar et al. (1999) did not find significant difference in the predation rate between the two nest phases of Euler's flycatcher (Lathrotriccus euleri, Cabanis 1868) (Tyrannidae). However, RoDRIGUEs \& CRICK (1997) found larger nest loss in the nestling phase for Chiffchaff (Phylloscopus collybita, Vieillot 1817) (Sylviidae) in the temperate region. Stagsvold (1982) suggested that predation rates are frequently larger during nestling phase because nests become more exposed to visualization by predators which are conducted by adult movement for nestlings feeding.

Predation is one of the factors most considered by theories that try to explain the evolution of bird colonial breeding (Brown 1975, Pleasants 1979, Wittenberger \& Hunt 1985, Wiklund \& Andersson 1994, Picman et al. 2002). Therefore, it is not surprising that the main cause of red-rumped cacique nests loss is predation as suggested in the present study. Besides, predation has also been considered as the largest factor of brood loss for several non-colonial bird species (ONIKI 1979, MARTIN 1993, Lopes \& MARINi 2005, Aguilar et al. 1999, 2000), reflecting the importance of knowing the factors associated with predation to define conservation strategies of bird species.

\section{Nest abandonment and fall}

Nest abandonment rate (23\%) before females laid eggs was possibly related with aggressive interactions between females. Robinson (1988) studying Yelllow-rumped cacique in Peru related that many young females began building nests and abandoned them later. This author considered that these females were the focus of intense aggression from adult females, which often expelled young and took over nest sites in which young females had begun to build. Besides, adult females of redrumped cacique often remove material used by young females to build their own nests (DUCA \& MARINi 2004), possibly causing nest abandonment. Only $11.6 \%$ out of 251 nests began by young females of yellow-rumped cacique were completed (Robinson 1988). It is possible that nest abandonment before eggs were laid and long period (about 60 days) of nest building by some females (DUCA \& MARINI 2004) are explained by similar reasons related above for yellow-rumped cacique in Peru. Curio (1983) and Procter-Gray \& Holmes (1981) discussed that the attempt of reproducing by young females is a way of obtaining experience and the energy cost is compensated with larger breeding success when they get older.

Nest abandonment after eggs were laid (6.6\%) and nest fall (6.1\%) were important causes of nest losses. ONIKI (1979), in studies conducted in Amazon, found similar nest abandonment rates (about 5.3\%). FEEKEs (1981) reported that disturbance, predation and bad weather often caused all birds to desert colonies leaving their offspring behind. Although GÖTMARK (1992) considers that the main disturbance caused by researchers in bird nests is abandonment of eggs and nestlings, it did not seem to be an important cause of red-rumped cacique nests abandonment in this study.
Feekes (1981) relates fall and tear of red-rumped cacique nests in Suriname only to strong wind gusts and rain, and RoBinson (1985) relates fall of yellow-rumped cacique nests only to accidental action of predators. In spite of other hypotheses, we believe that female behavior removing material from other nests (Duca \& Marini 2004) and fight between them are the main causes of red-rumped cacique nests fall in the study area. These agonistic interactions frequently happened on the nests, damaging their structure and leaving them more susceptible to unfasten later or provoking their immediate fall. One of the reasons to happen these aggressive interactions is the frequent behavior of females that steal material of other nests to use in the building of their own nest. Several times it was observed nests with eggs or nestlings having their structure damaged due to theft of material by other females (DuCA \& MarinI 2004).

\section{Breeding success}

The red-rumped cacique nest survival probability was 40.5\%. Smaller values were reported for Kirtland's warbler (Dendroica kirtlandii, Baird 1852) (Parulidae) (MAYFIELd 1961) and red-winged blackbird (WESTNEAT 1992), both with a nest survival probability of 32\%, and larger value was found for Kentucky warbler (Oporornis formosus, Wilson 1811) (Fringillidae) (SARGENT et al. 1997). The three studies mentioned above, however, were accomplished in the temperate region. Mason (1985), working in subtropical region, found nest survival probability varying from $6.8 \%$ to $71 \%$ for passerine species. Therefore, it was observed that the nest survival probability of bird species is highly variable and that the value found for red-rumped cacique is compatible with values from the literature mentioned above and with other tropical passerine (RicKLEFs \& BLOOM 1977).

The existence of a gradient in breeding success among the three environments considered here can be explained by an association of factors, which most likely were unchained by predation pressure. A similar gradient in the breeding success was also observed in colonies of red-rumped cacique and yellowrumped cacique in Suriname (FEEKEs 1981) and yellow-rumped cacique colonies in Peru (RoBINson 1985). These authors consider that the gradient in breeding success observed is a result of differentiated vulnerability of those environments to terrestrial and arboreal predators. According to RoBinson (1985), most cacique females that lose nests to a predator tend to select safer sites against that kind of predator. For this mechanism, the safest sites against predators accumulate the largest number of nests, promoting other benefits related to a larger number of nests and individuals (Robinson 1985, WikLund \& ANDERSSON 1994, PICMAN et al. 2002). In this study, we found a significant relationship between the number of nests with nests survival probability and failure percentage when we analyzed only the active nests on the period of time that the colonies from three environments were active. It suggests that the presence of larger number of nests increases nest survival probability of red-rumped cacique.

BURGER (1985) considers predation the factor that influences the most selection of breeding sites. MARTIN (1995) also

Revista Brasileira de Zoologia 25 (2): 165-171, June, 2008 
found consistent results with the prediction that birds select breeding sites in agreement with the predation risk. This author found a large variation in life history characteristics in the breeding sites of 123 bird species from North America, with 50-60\% of these characteristics being explained by a correlation between nest predation rate and the different breeding sites.

Even though in this study we did not detect a significant difference between predation rates during incubation and nestling periods, it was observed a larger nest survival probability during incubation period. KelLy (1993) also found a larger survival rate during incubation period for Dusky flycatcher (Empidonax oberholseri, Phillips 1939) (Tyrannidae), but this difference was not statistically significant. BEST \& STAUFFer (1980) found higher nest success during nestling than during incubation period for 10 out of 13 studied species.

The results presented here indicate that red-rumped cacique obtain higher breeding success in colonies established in swamp environments than the ones established in forest or lake edge. However, the difference in predation rate among the three environments was not significant, predation was the main cause of nests loss and it should be considered as an important factor supporting a higher breeding success and number of nests in the swamp environment.

\section{ACKNOWLEDGMENTS}

To CNPq and FAPEMIG for Mater's Scholarship to the first author. The second author received a Research Fellowship from CNPq. To Instituto Estadual de Floresta for logistics support during field work in the Parque Estadual do Rio Doce. T. Guerra helped with data collection. To G. Maecha, A.J. Piratelli and J.B. Pinho for reading a previous draft of the manuscript. Anonymous reviewers made suggestions to the manuscript.

\section{REFERENCES}

Aguilar, T.M.; L.O. Leite \& M.Â. Marini. 1999. Biologia de nidificação de Lathrotricus euleri (Cabanis 1968) (Tyrannidae) em fragmento de mata em Minas Gerais. Ararajuba 7 (2): 125-133.

Aguilar, T.M.; M. Maldonado-Coelho \& M.Â. Marini. 2000. Nesting biology of the Gray-hooded Flycatcher (Mionectes rufiventris). Ornitologia Neotropical 11 (3): 223-230.

Best, B.L. \& D.F. Stauffer. 1980. Factors effecting nesting success in riparian bird communities. The Condor 82 (2): 149-158.

BRown, J.L. 1975. The evolution of behavior. New York, W.W. Norton and Company, 760p.

Burger, J. 1985. Habitat selection in temperate marsh-nesting birds. In: M.L. Cody (Ed.). Habitat selection in birds. London, Academic Press, 558p.

Caccamise, D.F. 1976. Nesting mortality in the red-winged blackbird. The Auk 93 (3): 517-534.

Curio, E. 1983. Why do young birds reproduce less well? Ibis 125 (3): 400-404.

Duca, C. \& M.Â. Marini. 2004. Aspectos da nidificação de Cacicus haemorrhous (Passeriformes, Icterinae) no sudeste do Brasil. Ararajuba 12 (1): 25-32.

Feekes, F. 1981. Biology and organization of two sympatric Caciques, Cacicus c. cela and Cacicus h. haemorrhous (Icteridae, Aves) in Suriname. Ardea 69 (1): 83-107.

Foster, W.A. \& J.E. Treherne. 1981. Evidence for the dilution effect in the selfish herd from fish predation in marine insect. Nature 293 (5832): 466-467.

GötmaRK, F. 1992. The effects of investigator disturbance on nesting birds. Current Ornithology 9: 63-104.

Hoogland, J.L. \& P.W. Sherman. 1976. Advantages and disadvantages of Bank Swallow (Riparia riparia) coloniality. Ecological Monographs 46 (1): 33-58.

Horn, H.S. 1968. The adaptative significance of colonial nesting in Brewer's Blackbird (Euphagus cyanocephalus). Ecology 49 (4): 682-694.

KeLLY, J.P. 1993. The effect of nest predation on habitat selection by Dusky Flycatchers in Limber Pine-juniper Woodland. The Condor 95 (1): 83-93.

Lenington, S. 1980. Female choice and polygyny in red-winged blackbirds. Animal Behaviour 28 (2): 347-361.

LOPES, L.E. \& M.Â. MARINI. 2005. Low reproductive success of Campo Suiriri (Suiriri affinis) and Chapada Flycatcher (S. islerorum) in the central Brazilian Cerrado. Bird Conservation International 15 (4): 337-346

MarTin, T.E. 1993. Nest predation among vegetation layers and types: revising the dogmas. The American Naturalist 141 (6): 897-913.

Martin, T.E. 1995. Avian life history evolution in relation to nest sites, nest predation, and food. Ecological Monographs 65 (1): 101-127.

Mason, P. 1985. The nesting biology of some passerines of Buenos Aires, Argentina. Ornithological Monographs 36: 954-972.

Massoni, V. \& J.C. Reboreda. 2001. Number of close spatial and temporal neighbors decreases the probability of nest failure and Shiny Cowbird parasitism in colonial Yellow-winged Blackbirds. The Condor 103 (3): 521-529.

MaYField, H.F. 1961. Nesting success calculated from exposure. The Wilson Bulletin 73 (3): 255-261.

Mayfield, H.F. 1975. Suggestions for calculating nest success. The Wilson Bulletin 87 (4): 456-466.

Nisbet, I.C.T. \& M.J. Welton. 1984. Seasonal variations in breeding success of Common Terns: consequences of predation. The Condor 86 (1): 53-60.

ONIKI, Y. 1979. Is nesting success of bird low in the tropics? Biotropica 11 (1): 60-69.

Отт, L. 1988. An introduction to statistical methods and data analysis. Boston, PWS Publishing Company, $3^{\text {rd }}$ ed., 835p.

PARKes, K.C. 1970. A revision of the Red-rumped Cacique, Cacicus haemorrhous (Aves: Icteridae). Proceedings of the Biological Society Washington 83 (19): 203-214.

Picman, J.; S. Pribil \& A. Isabelle. 2002. Antipredation value of 
colonial nesting in Yellow-headed Blackbirds. The Auk 119 (2): 461-472.

Pleasants, B.Y. 1979. Adaptive significance of variable dispersion pattern of breeding Northern Orioles. The Condor 81 (1): 28-34.

Pleszczynska, W.K. 1978. Microgeographic prediction of polygyny in the lark bunting. Science 201 (4359): 935-937.

Procter-Gray, E. \& R.T. Holmes. 1981. Adaptive significance of delayed attainment of plumage in male American redstarts: test of two hypotheses. Evolution 35 (4): 742-751.

Ricklefs, R.E. \& G. Bloom. 1977. Components of avian breeding productivity. The Auk 94 (1): 86-96.

Ridgely, R.S. \& G. Tudor G. 1989. The birds of South America. University of Austin, Texas Press, vol. 1, 516p.

Robinson, S.K. 1985. Coloniality in the Yellow-rumped Cacique as a defense against nest predators. The Auk 102 (3): 506519.

Robinson, S.K. 1988. Anti-social and social behaviour of adolescent Yellow-rumped Caciques (Icterinae: Cacicus cela). Animal Behaviour 36 (5): 1482-1495.

Rodrigues, M. \& H.Q.P. Crick. 1997. The breeding biology of the Chiffchaff Phylloscopus collybita in Britain: a comparison of an intensive study with records of the BTO nest Record Scheme. Bird Study 44 (3): 374-383.

Sargent, R.A.; J.C. Kilgo; B.R. Chapman \& K.V. Miller. 1997. Nesting success of Kentucky and Hooded Warblers in Bottomland Forest of South Carolina. The Wilson Bulletin 109 (2): 233-238.

SıcK H. 1997. Ornitologia Brasileira. Uma Introdução. Brasília, Editora Nova Fronteira, 862p.

SIF. 1990. Plano Diretor do Parque Florestal Estadual do Rio Doce. Viçosa. Viçosa, Sociedade de Investigações Florestais, Instituto Estadual de Florestas, 99p.

Slagsvold, T. 1982. Clutch size variation in Passerine birds: the nest predation hypothesis. Oecologia 54 (2): 159-169.

StatSoft, Inc. 1995. STATISTICA for windows (Computer program manual). Tulsa, StatSoft.

TenAzA, R. 1971. Behavior and nesting success relative to nest location in Adélie penguins (Pygoscelis adeliae). The Condor 73 (1): 81-92.

Triola, M. F. 1999. Introdução a Estatística. Rio de Janeiro, Editora LTC7 ${ }^{\mathrm{a}}$ ed., 410p.

TundisI, J.G. \& Y. SAIJO. 1997. Limnological Studies on the Rio Doce Valley Lakes, Brazil. São Carlos, Brazilian Academy of Sciences, University of São Paulo School of Engineering, Center for Water Resources and Applied Ecology, 563p.

Veloso, H.P.; A.L.R. Rangel-Filho \& J.C.A. Lima. 1991. Classificação da vegetação brasileira adaptada a um sistema universal. Rio de Janeiro, Instituto Brasileiro de Geografia e Estatística, 123p.

Weatherhead, P.J. \& R.J.Robertson. 1977. Harem size, territory quality, and reproductive success in the Red-winged Blackbirds (Agelaius phoeniceus). Canadian Journal of Zoology 55 (8): 1261-1267.

Westneat, D.F. 1992. Nesting synchrony by female Red-winged Blackbirds: effects on predation and breeding success. Ecology 73 (6): 2284-2294.

WikLund, C.G. \& M. ANDERsson. 1994. Natural selection of colony size in a passerine bird. Journal of Animal Ecology 63 (4): 765-774.

Wittenberger, J.F. 1980. Vegetation structure, food supply, and polygyny in bobolinks (Dolichonyx oryzivorus). Ecology 61 (1): 140-150.

Wittenberger, J.F. \& L.J. Hunt. 1985. The adaptive significance of coloniality in birds. Avian Biology 8: 2-58.

YaSUKAWA, K. \& W.A. SEARCy. 1981. Nesting synchrony and dispersion in Red-winged Blackbirds: is the harem competitive or cooperative? The Auk 98 (4): 659-668.

Recebido em 16.X.2007; aceito em 18.III.2008.

Editorial responsibility: Lena Geise 